University of Nebraska - Lincoln

DigitalCommons@University of Nebraska - Lincoln

USDA National Wildlife Research Center - Staff Publications
U.S. Department of Agriculture: Animal and Plant Health Inspection Service

2018

\title{
Estimating densities for sympatric kit foxes (Vulpes macrotis) and coyotes (Canis latrans) using noninvasive genetic sampling
}

\author{
R. C. Lonsinger \\ South Dakota State University, robert.lonsinger@sdstate.edu \\ P. M. Lukacs \\ University of Montana \\ E. M. Gese \\ USDA National Wildlife Research Center \\ R. N. Knight \\ United States Army Dugway Proving Ground \\ L. P. Waits \\ University of Idaho
}

Follow this and additional works at: https://digitalcommons.unl.edu/icwdm_usdanwrc

Part of the Life Sciences Commons

Lonsinger, R. C.; Lukacs, P. M.; Gese, E. M.; Knight, R. N.; and Waits, L. P., "Estimating densities for sympatric kit foxes (Vulpes macrotis) and coyotes (Canis latrans) using noninvasive genetic sampling" (2018). USDA National Wildlife Research Center - Staff Publications. 2197.

https://digitalcommons.unl.edu/icwdm_usdanwrc/2197

This Article is brought to you for free and open access by the U.S. Department of Agriculture: Animal and Plant Health Inspection Service at DigitalCommons@University of Nebraska - Lincoln. It has been accepted for inclusion in USDA National Wildlife Research Center - Staff Publications by an authorized administrator of DigitalCommons@University of Nebraska - Lincoln. 


\title{
Estimating densities for sympatric kit foxes (Vulpes macrotis) and coyotes (Canis latrans) using noninvasive genetic sampling
}

\author{
R.C. Lonsinger, P.M. Lukacs, E.M. Gese, R.N. Knight, and L.P. Waits
}

\begin{abstract}
Kit fox (Vulpes macrotis Merriam, 1888) populations in the Great Basin Desert have declined and are of increasing concern for managers. Increasing coyote (Canis latrans Say, 1823) abundance and subsequent intraguild interactions may be one cause for this decline. Concurrent monitoring of carnivores is challenging and therefore rarely conducted. One possible solution for monitoring elusive carnivores is using noninvasive genetic sampling. We used noninvasive genetic sampling to collect fecal DNA from kit foxes and coyotes and estimate their densities from 2013-2014 in Utah, USA. We identified individuals based on microsatellite genotypes and estimated density with multisession spatially explicit capture-recapture models. Mean kit fox density was 0.02 foxes $\cdot \mathrm{km}^{-2}$, while coyote densities were up to four times greater $\left(0.07-0.08\right.$ coyotes $\left.\cdot \mathrm{km}^{-2}\right)$. Kit fox densities were significantly lower than densities in the 1950s but were comparable with estimates from the late 1990s, suggesting that populations may be stabilizing after a precipitous decline. Our kit fox density estimates were among the lowest documented for the species. Our coyote density estimate was the first reported in our region and revealed that despite seemingly high abundance, densities are low compared with other regions. Our results suggested that kit foxes may be able to coexist with coyotes.
\end{abstract}

Key words: Canis latrans, coyote, density, kit fox, noninvasive genetic sampling, spatial capture-recapture, Vulpes macrotis.

Résumé : Les populations de renards nains (Vulpes macrotis Merriam, 1888) dans le désert du Grand Bassin ont connu un déclin et préoccupent de plus en plus les aménagistes. L'abondance croissante des coyotes (Canis latrans Say, 1823) et les interactions intraguildes qui en découlent pourraient constituer une cause de ce déclin. Comme elle n'est pas facile à réaliser, la surveillance concurrente de carnivores est rarement effectuée. Une approche possible de surveillance de carnivores discrets consiste à utiliser l'échantillonnage génétique non invasif. Nous avons utilisé cette approche pour prélever de l'ADN de fèces de renards nains et de coyotes et estimer leurs densités en 2013-2014 en Utah (États-Unis). Nous avons identifié les individus à la lumière de génotypes de microsatellites et estimé la densité à l'aide de modèles de capture-recapture spatialement explicites multi-sessions. La densité moyenne de renards nains était de 0,02 renard $\cdot \mathrm{km}^{-2}$, alors que les densités de coyotes étaient jusqu'à quatre fois plus élevées $\left(0,07-0,08\right.$ coyote $\left.\cdot \mathrm{km}^{-2}\right)$. Les densités de renards nains étaient significativement plus faibles que dans les années 1950 , mais semblables aux densités estimées à la fin des années 1990, ce qui indiquerait que les populations pourraient être en train de se stabiliser après une baisse abrupte. Nos estimations de la densité de renards nains sont parmi les plus faibles documentées pour l'espèce. Notre estimation des densités de coyotes constitue la première estimation publiée pour cette région et révèle que, malgré une grande abondance apparente, ces densités sont faibles comparativement à celles d'autres régions. Nos résultats portent à croire que les renards nains pourraient être en mesure de coexister avec des coyotes. [Traduit par la Rédaction]

Mots-clés : Canis latrans, coyote, densité, renard nain, échantillonnage génétique non invasif, capture-recapture spatiale, Vulpes macrotis.

\section{Introduction}

To evaluate the effectiveness of management strategies intended to maintain harvested populations, control nuisance species, or conserve imperiled species, managers require reliable estimates of population density or abundance (Williams et al. 2002; Solberg et al. 2006; Brøseth et al. 2010; Granjon et al. 2017). Capture-recapture techniques can provide reliable estimates of abundance (Williams et al. 2002; Efford and Fewster 2013), but conventional methods of capture and recapture (e.g., live capture) are often challenging and cost-prohibitive for long-term monitoring (Pollock et al. 2002; Manning and Goldberg 2010). Capture- recapture analyses based on noninvasive genetic sampling (NGS) provide alternative strategies that have seen rapid technological advancements (Lukacs and Burnham 2005; Miller et al. 2005; Schwartz et al. 2007; Thompson et al. 2012) and increased use by practitioners (Brøseth et al. 2010; Stenglein et al. 2010b; Russell et al. 2012; Granjon et al. 2017). By using biological material (e.g., feces, hair) left in the environment to identify individuals (via unique genotypes), NGS can be coupled with capture-recapture techniques without the need to handle or observe individuals, an important consideration when dealing with taxa that are difficult to capture or sensitive to handling (Waits and Paetkau 2005;

Received 18 November 2017. Accepted 1 March 2018.

R.C. Lonsinger. Department of Natural Resource Management, South Dakota State University, Brookings, SD 57007, U.S.A.

P.M. Lukacs. University of Montana, Wildlife Biology Program, Department of Ecosystems and Conservation Sciences, W.A. Franke College of Forestry and Conservation, Missoula, MT 59812, U.S.A.

E.M. Gese. United States Department of Agriculture, Wildlife Services, National Wildlife Research Center, Department of Wildland Resources, Utah State University, Logan, UT 84322, U.S.A.

R.N. Knight. United States Army Dugway Proving Ground, Natural Resource Program, Dugway, UT 84022, U.S.A.

L.P. Waits. University of Idaho, Department of Fish and Wildlife Sciences, Moscow, ID 83844, U.S.A.

Corresponding author: Robert C. Lonsinger (email: robert.lonsinger@sdstate.edu).

Copyright remains with the author(s) or their institution(s). Permission for reuse (free in most cases) can be obtained from RightsLink. 
Schwartz et al. 2007). Consequently, NGS may increase sample sizes over conventional capture techniques and provide an efficient monitoring strategy that may be employed over extended spatial and temporal scales (Solberg et al. 2006; Brøseth et al. 2010; Stansbury et al. 2014).

The kit fox (Vulpes macrotis Merriam, 1888) is a species of conservation concern that is believed to be experiencing range-wide population declines (Dempsey et al. 2014); one subspecies, the San Joaquin kit fox (Vulpes macrotis mutica Merriam, 1902) is listed as federally endangered in the United States (U.S. Fish and Wildlife Service (USFWS) 1998). In the Great Basin Desert, kit foxes were the most abundant carnivore through the mid-1900s and were increasing in abundance during the 1950s (Egoscue 1956, 1962, 1975; Arjo et al. 2007). More recently, population declines have been documented (Arjo et al. 2007), and it has been suggested that declines may have been related to increasing coyote (Canis latrans Say, 1823) abundance (Arjo et al. 2007). No formal population estimates, however, have been conducted for coyotes in the Great Basin Desert over this period. Coyotes are often considered a nuisance species, and intraguild predation by coyotes is a major threat to kit fox persistence across their range (Nelson et al. 2007; Kozlowski et al. 2012). Coyotes have been documented as the primary cause of kit fox mortality at multiple sites (Cypher and Spencer 1998; Kozlowski et al. 2012), and coyote activity has been positively associated with local extinction of kit foxes (Lonsinger et al. 2017).

Carnivores tend to be elusive, occur in relatively low densities, and are wide-ranging, making them particularly challenging to monitor (Gese 2001). Efforts to monitor kit foxes and coyotes in the Great Basin Desert have included predator control indices, scat deposition surveys, live capture, den monitoring, and radiotelemetry (Arjo et al. 2007; Kozlowski et al. 2012; Kluever et al. 2013; Dempsey et al. 2014, 2015). Scat deposition surveys provide indices of relative abundance (Gese 2001) but may suffer from misidentification of sign (Lonsinger et al. 2015b) and often fail to account for spatiotemporal variation in scat detection (Kluever et al. 2015; Lonsinger et al. 2016). Live captures and radiotelemetry are expensive and time-consuming (Gese 2001), limiting the spatial and temporal extent of monitoring, and den monitoring often requires telemetered animals to locate dens (e.g., Arjo et al. 2003). Recent live-capture efforts in the Great Basin Desert for kit foxes experienced insufficient capture and recapture rates $(<1$ capture per 100 trap nights) to effectively estimate abundance (Kluever and Gese 2017). Similarly, despite live capture of coyotes in the Great Basin Desert via foothold traps and helicopter net-gunning (Kluever and Gese 2016), researchers relied on indices of relative abundance from scat deposition surveys to quantify population response to habitat manipulations (Kluever et al. 2017). Thus, managers still require cost-efficient and effective methods to monitor kit foxes and coyotes and would benefit from an approach that facilitates concurrent, long-term monitoring of these species over large spatial extents.

Here, we combined NGS and spatially explicit capture-recapture (SECR) models to monitor kit fox and coyote populations over four sessions within a 2-year period. For each species, our primary objectives were to generate likelihood-based estimates of density from multisession SECR models and derive estimates of abundance. We aimed to compare kit fox and coyote density estimates with one another and compare kit fox density estimates with historical estimates at our study site. Coyote density has not been estimated previously at our study site. Additionally, we aimed to use SECR models to explore the role of habitat features on spatial variation in each species' density. We predicted that the density of coyotes would be greater than that of kit foxes and that both species would have higher densities in summer (following annual reproduction and prior to juvenile dispersal) than in winter. We hypothesized that coyote densities would be positively associated with shrub cover (Nelson et al. 2007; Kozlowski et al. 2012; Lonsinger et al. 2017) and negatively associated with distance to water (Golightly and Ohmart 1984; Arjo et al. 2007). We hypothesized that kit fox densities would be negatively related to shrub cover and positively related to distance to water, owing to avoidance of coyote activity centers (Kozlowski et al. 2012).

\section{Materials and methods}

\section{Study area}

The study extent was approximately $3015 \mathrm{~km}^{2}$, encompassing the eastern portion of the U.S. Army's Dugway Proving Ground and surrounding lands (managed primarily by the U.S. Bureau of Land Management) in Tooele County, Utah, USA (Lonsinger et al. 2015b). The study extent (referred to collectively hereafter as Dugway) featured low-lying desert basins demarcated by abrupt range formations typical of the cold desert systems of the Great Basin Desert. Elevations ranged from approximately $1200 \mathrm{~m}$ to $2100 \mathrm{~m}$ above sea level (Arjo et al. 2007). Land cover at lower elevations included cold desert playa, cold desert chenopod shrubland, vegetated and unvegetated dunes, and non-native invasive grasslands. At higher elevations, arid shrubland and open woodland land-cover classes were common. Greasewood (Sarcobatus vermiculatus (Hook.) Torr.) shrubland was distributed across elevations (Lonsinger et al. 2017). Winters at Dugway were cold (January mean high temperature = $4{ }^{\circ} \mathrm{C}$ ) and summers were moderate (July mean high temperature $=$ $36{ }^{\circ} \mathrm{C}$; Lonsinger et al. 2015b). Annual mean precipitation was $\sim 20 \mathrm{~cm}$ (Arjo et al. 2007).

\section{Surveys and sample collection}

We conducted carnivore scat surveys over four primary sampling sessions, including two winters (January-March) and two summers (July-August) over 2 years (2013 and 2014). Fifteen $5 \mathrm{~km}$ transects were randomly distributed along dirt and gravel roads to monitor kit foxes and coyotes as part of another study (Dempsey et al. 2015), and we retained these transects. We selected 15 additional random transects by dividing the study area into $25 \mathrm{~km}^{2}$ cells (a size similar to the average size of a kit fox home range at Dugway; Dempsey et al. 2014), randomly selecting 15 cells without replacement and identifying a $5 \mathrm{~km}$ transect along dirt or gravel roads within each selected cell (Fig. 1; Lonsinger et al. 2015b). These 30 transects (hereafter, multi-occasion transects) were surveyed three to five times per session. We employed a sampling interval (the period between sampling occasions within a session) of 14 days, which has been shown to be an optimal temporal NGS design for kit foxes and coyotes in our system (Lonsinger et al. 2015a). As part of a concurrent study investigating canid occupancy dynamics, 60 sites (each $6.25 \mathrm{~km}^{2}$ ) were randomly selected from a grid of 576 cells superimposed on our study area and excluding cells containing portions of our multioccasion transects; within each of these sites, four transects (each $500 \mathrm{~m}$; hereafter, single-occasion transects) were established along roadways and surveyed once per session (Lonsinger et al. 2017). We surveyed all transects for carnivore scats with two observers. We recorded the location of each scat detected, collected $\sim 0.7 \mathrm{~mL}$ of fecal material from the side of the scat (Stenglein et al. $2010 a$ ) into $1.4 \mathrm{~mL}$ of DETS buffer (20\% DMSO, $0.25 \mathrm{~mol} \cdot \mathrm{L}^{-1}$ EDTA, $100 \mu \mathrm{mol} \cdot \mathrm{L}^{-1}$ Tris, $\mathrm{pH} 7.5$, and $\mathrm{NaCl}$ to saturation; Seutin et al. 1991), and removed remaining portions of the scat.

Noninvasive fecal DNA can suffer from low DNA amplification success and genotyping errors (Waits and Paetkau 2005). Considering these challenges, previous NGS research using fecal DNA for capture-recapture analyses recommended collecting 2.5-3 times as many scat samples as the number of individuals expected in the population (Solberg et al. 2006) to ensure a sufficient number of captures and recaptures. Rates of scat accumulation were lower in winter than in summer for both kit foxes and coyotes (Lonsinger et al. 2015a), and consequently, we conducted four or five surveys during winter and three or four surveys during summer on each 
Fig. 1. Trapping grid superimposed on $5 \mathrm{~km}$ multi-occasion and $500 \mathrm{~m}$ single-occasion scat deposition transects to identify conceptual traps (grid centers) for spatially explicit capture-recapture analysis of kit foxes (Vulpes macrotis) and coyotes (Canis latrans) in the Great Basin Desert (2013-2014). Single-occasion and multi-occasion traps represent those grid cells that were surveyed, with the value indicating the total length of transects within the cell; session-specific effort for cells with multi-occasion traps is the length of transects times the session-specific number of surveys.

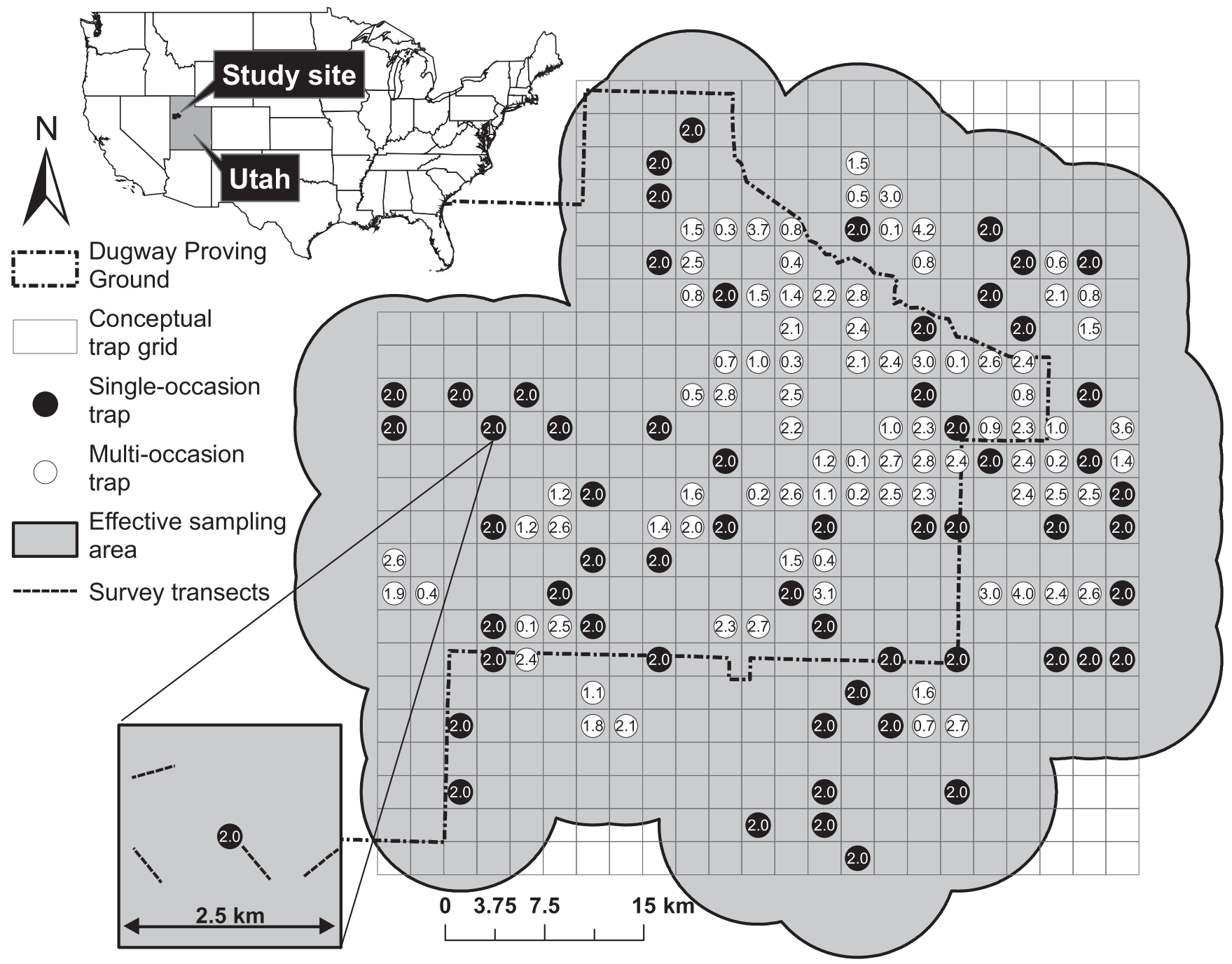

of the $5 \mathrm{~km}$ multi-occasion transects. We expected these levels of effort to yield sample sizes for kit foxes that were $\geq 3$ times the expected population sizes (Solberg et al. 2006). Rates of scat accumulation were greater for coyotes than kit foxes (Lonsinger et al. 2015a); therefore, we expected this level of effort to be sufficient for coyotes. To reduce costs during the final sampling occasion (i.e., final occasion of summer 2014), we collected only scats believed to be from kit foxes based on size (Lonsinger et al. 2015b).

\section{Genetic analysis}

We performed DNA extraction and polymerase-chain reaction (PCR) amplification in a laboratory dedicated to low-quality samples to minimize contamination risk. We determined species identification for scats using mitochondrial DNA (mtDNA; De Barba et al. 2014) and followed DNA storage, extraction, amplification, and scoring methods detailed in Lonsinger et al. (2015a).

For individual identification of kit fox samples, we amplified samples with primers for nine nuclear DNA (nDNA) microsatellite loci: Cxx103 (Holmes et al. 1995); Cxx250 (Ostrander et al. 1993); Cxx377 (Ostrander et al. 1995); FH2001, FH2010, FH2054, and FH2088 (Francisco et al. 1996); CPH3 (Fredholm and Wintero 1995); and
VVE-M19 (Cullingham et al. 2006). These loci were combined with two sex identification primers (CF-hprt and VV-sry; Berry et al. 2007) into a single multiplex. The PCR conditions for the $7 \mu \mathrm{L}$ (total volume) multiplex for each primer pair were $0.29 \mu \mathrm{mol} \cdot \mathrm{L}^{-1}$ Cxx103, $0.09 \mu \mathrm{mol} \cdot \mathrm{L}^{-1}$ VVE-M19, $0.06 \mu \mathrm{mol} \cdot \mathrm{L}^{-1} \mathrm{FH} 2054,0.04 \mu \mathrm{mol} \cdot \mathrm{L}^{-1}$ Cxx250, FH2001, FH2010, and CPH3, $0.03 \mu \mathrm{mol} \cdot \mathrm{L}^{-1} \mathrm{FH} 2088$ and CF-hprt, and $0.01 \mu \mathrm{mol} \cdot \mathrm{L}^{-1} \mathrm{Cx} \times 377$ and $V \mathrm{~V}$-sry, combined with $1 \times$ concentrated Qiagen Master Mix, $0.5 \times$ concentrated Q solution, and $1 \mu \mathrm{L}$ of DNA extract. The PCR thermal profile had an initial denaturation of $94{ }^{\circ} \mathrm{C}$ for $15 \mathrm{~min}, 15$ touchdown cycles at $94{ }^{\circ} \mathrm{C}$ for $30 \mathrm{~s}$ (denaturation), $63^{\circ} \mathrm{C}$ for $90 \mathrm{~s}$ (annealing; decreasing by $0.5^{\circ} \mathrm{C}$ per cycle) and $72{ }^{\circ} \mathrm{C}$ for $60 \mathrm{~s}$ (elongation), 20 cycles at $94{ }^{\circ} \mathrm{C}$ for $30 \mathrm{~s}$ (denaturation), $55^{\circ} \mathrm{C}$ for $90 \mathrm{~s}$ (annealing) and $72{ }^{\circ} \mathrm{C}$ for $60 \mathrm{~s}$ (elongation), and a final elongation at $60^{\circ} \mathrm{C}$ for $30 \mathrm{~min}$.

For individual identification of coyote samples, we amplified samples with primers for nine nDNA microsatellite loci: $C x \times 119$ (Holmes et al. 1995); Cxx173 (Ostrander et al. 1993); FH2001, FH2054, FH2088, and FH2137 (Francisco et al. 1996); FH2611 (Eichmann et al. 2004); and FH2670 and FH3725 (Guyon et al. 2003). These loci were combined with two sex identification primers (DBX6 and DBY7; 
Seddon 2005) into a single multiplex. The PCR conditions for the $7 \mu \mathrm{L}$ (total volume) multiplex for each primer pair were $0.11 \mu \mathrm{mol} \cdot \mathrm{L}^{-1}$ Cxx119, $0.07 \mu \mathrm{mol} \cdot \mathrm{L}^{-1} \mathrm{FH} 2670,0.05 \mu \mathrm{mol} \cdot \mathrm{L}^{-1} \mathrm{FH} 2611$ and DBX6, $0.04 \mu \mathrm{mol} \cdot \mathrm{L}^{-1} \mathrm{FH} 2001, \mathrm{FH} 3725$, and DBY7, $0.03 \mu \mathrm{mol} \cdot \mathrm{L}^{-1} \mathrm{FH} 2054$, FH2088, and FH2137, and $0.02 \mu \mathrm{mol} \cdot \mathrm{L}^{-1} \mathrm{Cxx} 173$, combined with $1 \times$ concentrated Qiagen Master Mix, $0.5 \times$ concentrated $Q$ solution, and $2 \mu \mathrm{L}$ of DNA extract. The PCR thermal profile had an initial denaturation of $94{ }^{\circ} \mathrm{C}$ for $15 \mathrm{~min}, 13$ touchdown cycles at $94{ }^{\circ} \mathrm{C}$ for $30 \mathrm{~s}$ (denaturation), $62{ }^{\circ} \mathrm{C}$ for $90 \mathrm{~s}$ (annealing; decreasing by $0.4{ }^{\circ} \mathrm{C}$ per cycle), and $72{ }^{\circ} \mathrm{C}$ for $60 \mathrm{~s}$ (elongation), 28 cycles at $94^{\circ} \mathrm{C}$ for $30 \mathrm{~s}$ (denaturation), $57^{\circ} \mathrm{C}$ for $90 \mathrm{~s}$ (annealing), and $72{ }^{\circ} \mathrm{C}$ for $60 \mathrm{~s}$ (elongation), and a final elongation at $60^{\circ} \mathrm{C}$ for $30 \mathrm{~min}$.

We conducted all PCR procedures on a BioRad Tetrad thermocycler (Bio-Rad, Hercules, California, USA) with negative and positive controls included with each reaction. We visualized results using a 3130xl DNA Analyzer (Applied Biosystems, Inc., Foster City, California, USA) and scored allele sizes with Genemapper 3.7 (Applied Biosystems, Inc.).

To minimize genotyping errors, we employed multiple methods. We dropped low-quality samples failing species identification (Kohn et al. 1999). For individual identification, we used a multiple-tube approach (Taberlet et al. 1996) and initially amplified each sample in two PCR replicates, dropping samples that failed at $>50 \%$ of nDNA loci (Paetkau 2003). For those retained, we performed additional PCR replicates in duplicate until consensus genotypes were achieved across loci or we reached eight replicates for kit foxes or six replicates for coyotes. We compared replicates and established consensus genotypes with ConGenR (Lonsinger and Waits 2015), which requires that alleles of heterozygous and homozygous genotypes be observed $\geq 2$ and $\geq 3$ times, respectively. For each species, we used samples collected in winter 2013 that achieved consensus genotypes across all loci and matched $\geq 1$ other sample (kit fox $=24$; coyote $=79$ ) to calculate the probability that two siblings have identical multilocus genotypes $\left(P(I D)_{\text {sibs }}\right.$; Waits et al. 2001) with GenAlEx 6.5 (Peakall and Smouse 2006). We then identified the number of loci required to reliably distinguish individuals at $P(I D)_{\text {sibs }}<0.01$ for each species (Waits et al. 2001). We culled samples that failed to achieve consensus genotypes at a sufficient number of loci. We compared samples with identical or near-identical multilocus genotypes (Creel et al. 2003) with ConGenR (Lonsinger and Waits 2015) and re-evaluated scoring of near matches to check for inconsistencies. For matches, we considered consistency in sex identification and compared intersample distances (Smith et al. 2006), scrutinizing and re-analyzing potential conflicts. We estimated genotyping error rates with ConGenR, which quantifies genotyping error rates by comparing replicated genotypes with their respective consensus genotype (Lonsinger and Waits 2015). We evaluated the reliability of multilocus genotypes observed only once (i.e., single-capture individuals) with RELIOTYPE (Miller et al. 2002) and retained samples with a reliability of $\geq 99 \%$.

\section{Minimum counts and capture-recapture analyses}

For each species, we used the number of unique multilocus genotypes identified within each session to represent a naïve minimum count. Individuals of both species have the capacity to emigrate from and subsequently return to Dugway. Thus, we did not include individuals into the minimum count for a session unless the individual was detected during that session. For example, an individual detected only in winter 2013 and winter 2014 was not included in summer 2013, as it could have left the study area.

Covariates used to model spatial variation in density for each species were obtained from available GIS layers, and we processed all layers with ArcGIS 10.3 (ESRI, Redlands, California, USA). Soil was expected to influence kit foxes, which use burrows yearround (Arjo et al. 2003), and has been documented to influence local colonization rates (Lonsinger et al. 2017). We obtained a soil layer from Utah's Automated Geographic Reference Center (http:// gis.utah.gov/) and reclassified soils into four categories (silt, fine sand, blocky loam, and gravel; sensu Dempsey et al. 2015). Vegetation data were obtained from the 2012 LANDFIRE program (http://landfire.cr.usgs.gov/) and reclassified into six land-cover forms (woodland, shrubland, subshrubs, grasslands, sparsely vegetated, and developed). From this, the proportion of cover attributable to shrubland and woodland was calculated, representing land cover related to coyote and kit fox occupancy (Lonsinger et al. 2017). Areas with greater shrubland and woodland cover were expected to support greater densities of shared mammalian prey (Kozlowski et al. 2008, 2012; Byerly et al. 2018). Water was expected to influence space use of carnivores in this arid environment (Arjo et al. 2007). We identified water sources based on Dugway Natural Resource Program GIS layers, satellite imagery, and field surveys (Lonsinger et al. 2017).

We developed encounter histories for individuals of each species within each session. Following the procedures of Thompson et al. (2012) and Russell et al. (2012), we superimposed a grid over the study area and used the centroid of each grid cell as a "conceptual" trap (Fig. 1). With this approach, detections of individuals within a grid cell were assigned to their respective cells centroid, effectively treating multiple detections of the same individual within a grid cell during a single survey (i.e., clusters) as a single detection and reducing the influence of spatial autocorrelation on density estimates (Thompson et al. 2012). Captures of an individual across multiple traps within a single occasion can be used to characterize the spatial point process (Borchers and Efford 2008).

With a goal of monitoring kit foxes and coyotes concurrently, we selected a grid size of $6.25 \mathrm{~km}^{2}(2.5 \times 2.5 \mathrm{~km})$ by considering the home range sizes of kit foxes (2.5-11.6 km²; List and Cypher 2004) and coyotes (5.5-6.9 $\mathrm{km}^{2}$; Gese et al. 1988; Nelson et al. 2007) across their ranges. Hall et al. (2013) and Kluever et al. (2017) used a spacing of $2.6 \mathrm{~km}$ between survey sites for canids at Dugway, a distance that they derived from the home ranges of coyotes in arid environments (Nelson et al. 2007), as an approximation of the mean daily movement distances. Thus, we expected that our grid (for which each conceptual trap was $2.5 \mathrm{~km}$ apart) would provide sufficient spacing to capture individuals in multiple conceptual traps. The grid aligned with that used to identify single-occasion sites, and each of these sites represented one trap. Additionally, the grid intersected longer, multi-occasion transects, demarcating multiple traps from each transect. Effort varied across transects and grid cells. To account for variation in effort among conceptual traps, we represented effort for each conceptual trap by the total length of transects surveyed within each grid cell (where repeat surveys on multi-occasion transects were summed; Fig. 1).

We fit SECR models by maximizing the full likelihood with the R package "secr" (Efford 2015; R Core Team 2015) and using a multisession formulation, which allows for improved estimation of parameters shared across sessions (Efford et al. 2009). In addition to generating density estimates $(\hat{D})$, SECR models estimate g0 and $\sigma$, which jointly describe the change in detectability with increasing distance from an animal's activity center (Efford et al. 2009). We used a half-normal detection function (or circular bivariate normal home range) in which g0 and $\sigma$ represent the intercept and scale parameter, respectively (Efford et al. 2009). To estimate density and derive an estimate of abundance $(\hat{N}=\hat{D} \times$ effective sampling area), the effective sampling area (i.e., the state space) must be appropriately defined. We evaluated the effect of buffer width around traps by considering changes in the loglikelihood, $\hat{D}$, and the effective sampling area while increasing widths from 1 to $15 \mathrm{~km}$. We selected the width at which the rate of change in both the log-likelihood and effective sampling area stabilized and $\hat{D}$ stabilized at the fifth decimal place. We applied this buffer around traps, creating a habitat mask with grid points evenly distributed every $2.5 \mathrm{~km}$; spatial covariates characterizing the area around each point (within a $1.25 \mathrm{~km}$ radius) - the 
Table 1. Survey effort for kit fox (Vulpes macrotis) and coyote (Canis latrans) fecal DNA samples used to estimate density of each species in western Utah, USA, over winter (W) and summer (S) sessions from 2013 to 2014.

\begin{tabular}{lllllll}
\hline & \multicolumn{2}{l}{$\begin{array}{l}\text { Multi-occasion } \\
\text { transects }(30)^{a}\end{array}$} & & \multicolumn{2}{l}{$\begin{array}{l}\text { Single-occasion } \\
\text { transects }(60)^{b}\end{array}$} & \\
\cline { 2 - 3 } Session & Occasions & Total $(\mathrm{km})$ & & Occasion & Total $(\mathrm{km})$ & Total $(\mathrm{km})$ \\
\hline W 2013 & 4 & 600 & & 1 & 120 & 720 \\
S 2013 & 3 & 450 & & 1 & 120 & 570 \\
W 2014 & 5 & 750 & & 1 & 120 & 870 \\
S 2014 & 4 & $600^{c}$ & 1 & 120 & 720 \\
\hline
\end{tabular}

${ }^{a}$ Multi-occasion transects were $5 \mathrm{~km}$ in length.

${ }^{b}$ Single-occasion transects each totaled $2 \mathrm{~km}$ in length (four $500 \mathrm{~m}$ transects).

'Summer 2014 totals reflect effort for kit fox; coyote samples were not collected on the final sampling occasion of multi-occasion transects (coyote multisession effort $=450 \mathrm{~km}$ ).

Table 2. Number of scats detected during fecal DNA surveys identified as kit fox (Vulpes macrotis), coyote (Canis latrans), non-target carnivore (NTC) species, a mixed sample, or a failed sample based on mitochondrial DNA species identification, minimum counts of individuals (Ind.) based on unique multilocus genotypes, and proportion male (M) in western Utah, USA, over winter (W) and summer (S) sessions from 2013 to 2014.

\begin{tabular}{|c|c|c|c|c|c|c|c|c|}
\hline \multirow[b]{2}{*}{ Session } & \multicolumn{2}{|c|}{ Kit fox } & \multicolumn{2}{|c|}{ Coyote } & \multicolumn{3}{|l|}{ Other } & \multirow[b]{2}{*}{ Tota } \\
\hline & $\overline{\text { Scats }}$ & Ind. (M) & $\overline{\text { Scats }}$ & Ind. (M) & $\overline{\text { NTC }^{a}}$ & Mixed $^{b}$ & $\overline{\text { Failed }}$ & \\
\hline W 2013 & 151 & $40(0.68)$ & 378 & $128(0.54)$ & 9 & 3 & 61 & 602 \\
\hline S 2013 & 175 & $36(0.56)$ & 626 & $128(0.47)$ & 37 & 10 & 230 & 1078 \\
\hline W 2014 & 301 & $50(0.58)$ & 645 & $141(0.51)$ & 23 & 16 & 28 & 1013 \\
\hline S 2014 & 183 & $38(0.47)$ & 725 & $151(0.52)$ & 23 & 15 & 113 & 1059 \\
\hline Total & 810 & $109(0.60)$ & 2374 & $302(0.53)$ & 92 & 44 & 432 & 3752 \\
\hline
\end{tabular}

${ }^{a}$ Non-target carnivores (NTC) included domestic dog, red fox, bobcat, and cougar.

${ }^{b}$ Mixed samples contained mitochondrial DNA from $>1$ species.

majority soil type and habitat, the proportion of shrubland and woodland cover, and the mean distance to water - were extracted for modeling $\hat{D}$.

We first evaluated capture models in which g0 and $\sigma$ varied across sessions and were either constant or varied by time, trend, or sex within sessions. Additionally, we considered both interaction and additive effect models of sex with time and trend. We then used the best-fit capture model when fitting models for $\hat{D}$. Models formulated for $\hat{D}$ allowed variation among sessions. Additionally, we fit models of $\hat{D}$ (overall and by sex) using the aforementioned spatial covariates believed to influence kit fox and (or) coyote space use and combinations of these predictors. We also considered models including a linear trend, as we expected that kit fox and coyote densities may increase and decrease, respectively, from east to west at Dugway. We used Akaike's information criterion with small sample size correction ( $\mathrm{AIC}_{\mathrm{c}}$ ) and Akaike weights to compare the relative fit of models for each species (Burnham and Anderson 2002). Single top models of capture and $\hat{D}$ could be identified within each species' model set, with the next closest model having little to no support based on $\Delta \mathrm{AIC}_{\mathrm{c}}$. We calculated $\hat{N}$ and confidence bounds by multiplying sessionspecific $\hat{D}$ and associated confidence limits by the effective sampling area (Russell et al. 2012).

\section{Results}

\section{Surveys, genetic analysis, and minimum counts}

Within each session, $570-870 \mathrm{~km}$ of transects were surveyed (Table 1). The mean time between multi-occasion transect surveys (within a session) was $\sim 14$ days (mean \pm standard deviation $(\mathrm{SD})=$ $13.7 \pm 0.93$ days, range $=9-18$ days), with departures from 14 days resulting from limited access (e.g., military training activities). We collected 3752 carnivore scats (Table 2). We observed high mtDNA amplification rates, with successful species identification for $93.3 \%$ of winter and $82.8 \%$ of summer samples. We identified $21.6 \%$ and $63.3 \%$ of samples as kit fox and coyote, respectively (Table 2).
Only $2.5 \%$ of samples were non-target carnivores, $1.1 \%$ were mixed (i.e., contained DNA of $>1$ species), and $11.5 \%$ failed (Table 2 ).

Six loci were required to achieve a $P(I D)_{\text {sibs }}<0.01$ for kit foxes, excluding sex identification markers. Kit fox individual identification success rates (i.e., the proportion of samples identified to species for which a successful individual identification was achieved) ranged from 59.4\% (summer 2013) to 91.4\% (winter 2013). Across sessions, 109 kit foxes were identified (Table 2), among which 102 individuals had consensus genotypes at $\geq 8$ loci. Sex was determined for all individuals. We captured 36-50 kit foxes in each session (Table 2; Fig. 2) and 37 individuals across $\geq 2$ sessions. We captured more males (60\%) than females (Table 2). For samples in the final dataset, genotyping error rates per multilocus genotype were relatively low (overall allelic dropout rate $=17.3 \%$; overall false allele rate $=3.4 \%$ ), suggesting that the probability of a genotyping error was low when the mean number of replicates (5) was performed (i.e., $\left.(0.1733+0.0342)^{5}=3.85 \times 10^{-4}\right)$.

Five loci were required to achieve a $P(\text { ID })_{\text {sibs }}<0.01$ for coyotes, excluding sex identification markers. Coyote individual identification success rates ranged from 63.1\% (summer 2013) to $90.2 \%$ (winter 2013). Across sessions, 302 coyotes were identified (Table 2), among which we obtained consensus genotypes across $\geq 8$ loci for 296 individuals and sex identification for all individuals. We captured 128-151 coyotes during each session (Table 2; Fig. 2), with 140 individuals being captured in multiple sessions. Overall, 53\% of captured coyotes were male (Table 2). Genotyping error rates per multilocus genotype were relatively low (overall allelic dropout rate $=14.7 \%$; overall false allele rate $=4.2 \%$ ) for samples in the final dataset, resulting in a low probability of a genotyping error (i.e., $\left.(0.1472+0.0418)^{5}=2.41 \times 10^{-4}\right)$ at the mean number of replicates (5).

\section{Spatial capture-recapture analyses}

Transects were distributed within 146 conceptual traps (Fig. 1) with a mean distance of $2.7 \mathrm{~km}$ between traps. Effort remained 
Fig. 2. Derived abundance estimates from multisession spatial capture-recapture models for kit foxes (Vulpes macrotis; solid circles) and coyotes (Canis latrans; solid squares) with $95 \%$ confidence intervals in western Utah, USA, over winter (W) and summer (S) sessions from 2013 to 2014. Open symbols indicate the minimum number of kit foxes (circles) and coyotes (squares) identified within each session based on unique multilocus genotypes.

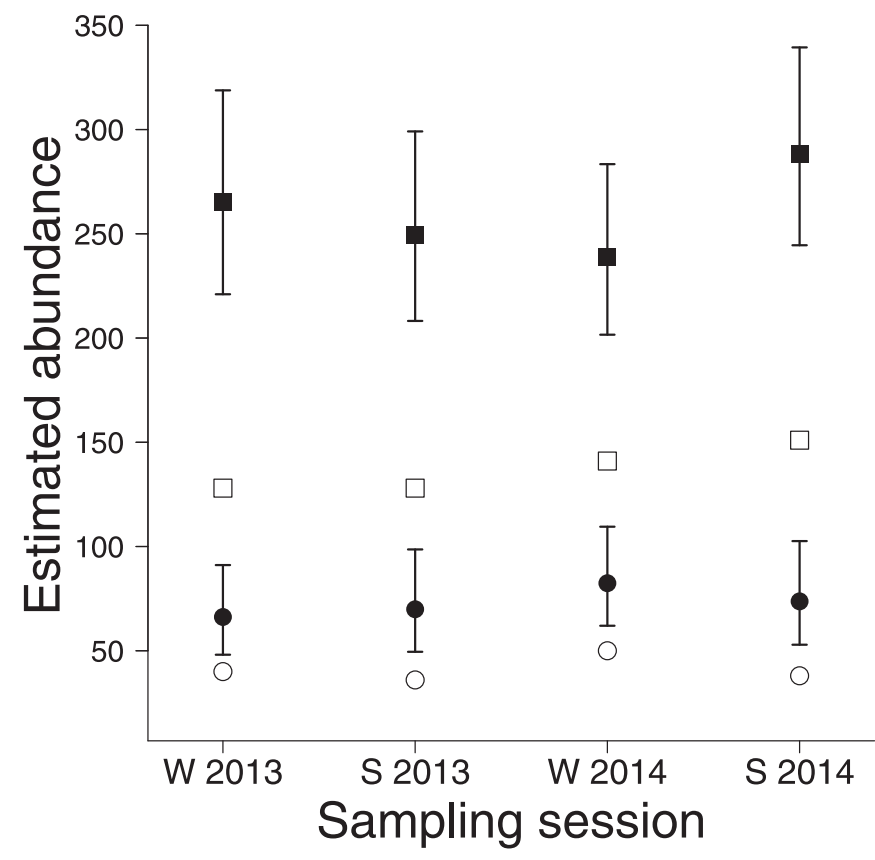

constant across sessions at conceptual traps characterized by single-occasion transects $(2 \mathrm{~km})$ but varied across sessions for traps associated with grid cells incorporating multi-occasion transects. Mean effort across sessions and species for multi-occasion sites was $4.9 \mathrm{~km}(\mathrm{SD}=4.0 \mathrm{~km}$; range $=<1-21 \mathrm{~km})$. For both species, the change in effective sampling area, log-likelihood, and $\hat{D}$ stabilized at a buffer width of $7.5 \mathrm{~km}$, resulting in a state space of $3663 \mathrm{~km}^{2}$ (Fig. 1).

Among the 12 capture models for $g 0$ and $\sigma$, the top kit fox model included variation among sessions and a trend in capture parameters within sessions (Table 3). The next closest model was $>23 \Delta \mathrm{AIC}_{\mathrm{c}}$ from the top model, indicating relatively little or no support (Table 3). Similarly, the top coyote capture model included variation among sessions and time-varying capture parameters within sessions, and the next closest model was $>68 \Delta \mathrm{AIC}_{\mathrm{c}}$ from the top model (Table 3). We attempted to fit 24 models of density for each species. Models containing the covariate distance to nearest water failed to converge, so we rescaled this parameter to mean $=0$ and $\mathrm{SD}=1$ but failed to achieve convergence. Consequently, we fit 14 models for each species (Appendix Table A1). For both species, the null model of density varying only by sampling session (i.e., $D \sim$ session) received the greatest support, with the next closest kit fox and coyote models having $\Delta \mathrm{AIC}_{\mathrm{c}}$ values of $>136$ and $>728$, respectively (Appendix Table A1). We used $\hat{D}$ from these top models to estimate abundances. Kit fox $\hat{D}$ was similar across sessions $\left(0.018-0.022\right.$ animals $\cdot \mathrm{km}^{-2}$; Table 4$)$. Coyote $\hat{D}(0.065-$ 0.079 animals $\cdot \mathrm{km}^{-2}$ ) was three to four times greater than that of kit foxes (Table 4).

Kit fox derived $\hat{N}$ ranged from 66 to 82 across sessions, whereas coyote $\hat{N}$ was significantly higher, ranging from 239 to 288 (Fig. 2). Within each species, the high degree of overlap in $95 \%$ confidence intervals among sessions suggested that populations were relatively stable during the study (Fig. 2). We did not detect significant differences in seasonal abundance (summer vs. winter) for either species. For both species, $\hat{N}$ was significantly higher than the minimum counts across sessions (Fig. 2).

\section{Discussion}

Noninvasive genetic sampling can increase detection of elusive species over traditional live capture (Kelly et al. 2012; Mumma et al. 2015), and SECR modeling can minimize problems associated with movement of wide-ranging species on the periphery of a study area (Blanc et al. 2013; Morin et al. 2016). Furthermore, concurrent sampling of sympatric species can reduce costs compared with monitoring species independently (Williams et al. 2009; Lonsinger et al. 2015a). Kit foxes are managed at Dugway as a species at risk and have been the focus of monitoring and research since the 1950s (Egoscue 1956; Arjo et al. 2007); still, density estimates were rarely generated due to challenges in capturing and monitoring a sufficient number of individuals (Arjo et al. 2007). Although coyotes impact kit foxes through intraguild predation and, therefore, are of management interest (Arjo et al. 2007; Kozlowski et al. 2012; Lonsinger et al. 2017), managers have relied primarily on indices of relative abundance for coyotes due to challenges in capturing a sufficient number of individuals to quantify population size (Arjo et al. 2007; Kluever et al. 2017). We demonstrated that NGS could be effectively combined with SECR modeling in our study area to concurrently generate estimates of density for sympatric kit foxes and coyotes. In contrast to our predictions though, we did not detect spatial variation in density, nor did we have sufficient precision to detect seasonal changes in density for either species.

\section{Kit fox density}

Kit foxes were reportedly the most abundant carnivore at Dugway in the 1950s and 1960s, with densities from 1955-1958 and 19661969 ranging from 0.15 to 0.22 and from 0.10 to 0.21 foxes $\cdot \mathrm{km}^{-2}$, respectively (Egoscue 1956, 1962, 1975; Arjo et al. 2007). Between 1997 and 2001, kit fox densities were estimated to have declined to $0.02-0.06$ foxes $\cdot \mathrm{km}^{-2}$ (Arjo et al. 2007); our mean density estimate of 0.02 foxes $\cdot \mathrm{km}^{-2}$ is comparable, supporting the conclusions of previous researchers that kit fox populations have declined significantly. Although comparisons of estimates of kit fox densities over time should be viewed with prudence because of differences in methodology and study extent, the study extents used at Dugway to estimate density of kit foxes have all been centered on the same desert basin and therefore likely reflect similar environmental conditions.

Comparisons of kit fox density estimates between Dugway and other regions suggest that foxes in Utah's West Desert may be at greater risk than previously recognized. White and Garrott (1999) highlighted the "marked instability" of kit fox populations, noting that the environmental stochasticity of desert climates can drive rapid changes in fox densities. Estimates of endangered San Joaquin kit fox populations demonstrated this instability, with densities from three sites in California varying from 0.12 to 0.24 foxes $\mathrm{km}^{-2}$ (Carrizo Plain Natural Area), 0.2 to 1.7 foxes $\cdot \mathrm{km}^{-2}$ (Naval Petroleum Reserves), and 0.7 to 15.2 foxes $\cdot \mathrm{km}^{-2}$ (Camp Roberts Army National Guard Training Site), respectively, over relatively short periods (Ralls and White 1995; White and Garrott 1999). Historical estimates of kit fox density in Utah (Egoscue 1956, 1962, 1975) were comparable with some estimates observed in California, as well as estimates from Arizona (0.220.28 foxes $\cdot \mathrm{km}^{-2}$; Zoellick and Smith 1992), but were lower than estimates in West Texas ( 0.39 foxes $\cdot \mathrm{km}^{-2}$; McLaughlin 1979). Our estimates suggest that kit fox population densities at Dugway have declined markedly and are currently lower than estimates reported in other regions.

\section{Coyote density}

Coyotes were native to the Great Plains of central North America through the early 1800 s, but expanded their distribution in re- 
Table 3. Top four models and null model for multisession spatial capture-recapture models for $g 0$ and $\sigma$ (which jointly describe capture probability) fit for kit foxes (Vulpes macrotis) and coyotes (Canis latrans) in western Utah, USA, from 2013 to 2014, ranked based on Akaike's information criterion with small sample size correction $\left(\mathrm{AIC}_{\mathrm{c}}\right)$ and differences in $\mathrm{AIC}_{\mathrm{c}}\left(\Delta \mathrm{AIC}\right.$, where $\left.\Delta_{i}=\mathrm{AIC}_{c i}-\mathrm{AIC}_{\mathrm{cmin}}\right)$ and reported with number of parameters $(K)$, Akaike weight $\left(w_{i}\right)$, and log-likelihood (LL).

\begin{tabular}{|c|c|c|c|c|c|c|c|c|c|c|c|}
\hline \multirow[b]{2}{*}{ Model $^{a, b, c}$} & & \multicolumn{5}{|c|}{ Kit fox } & \multicolumn{5}{|c|}{ Coyote } \\
\hline & & $K$ & $\mathrm{AIC}_{\mathrm{c}}$ & $\Delta \mathrm{AIC}_{\mathrm{c}}$ & $w_{\mathrm{i}}$ & $\mathrm{LL}$ & K & $\mathrm{AIC}_{\mathrm{c}}$ & $\Delta \mathrm{AIC}_{\mathrm{c}}$ & $w_{\mathrm{i}}$ & LL \\
\hline$g 0 \sim \mathrm{T} \times$ session & $\sigma \sim \mathrm{T} \times$ session & 20 & 3146.569 & 0 & 1 & -1550.348 & 20 & 9468.274 & 68.924 & 0 & -4713.339 \\
\hline$g 0 \sim \mathrm{t} \times$ session & $\sigma \sim \mathrm{t} \times$ session & 44 & 3169.765 & 23.196 & 0 & -1524.244 & 44 & 9399.350 & 0 & 1 & -4651.731 \\
\hline$g 0 \sim \mathrm{t}+$ session & $\sigma \sim \mathrm{t}+$ session & 20 & 3178.621 & 32.052 & 0 & -1566.373 & 20 & 9502.588 & 103.238 & 0 & -4730.496 \\
\hline$g 0 \sim \mathrm{T}+$ session & $\sigma \sim \mathrm{T}+$ session & 14 & 3215.218 & 68.649 & 0 & -1592.200 & 14 & 9537.492 & 138.142 & 0 & -4754.351 \\
\hline g0 $\sim$ session & $\sigma \sim$ session & 12 & 3220.637 & 74.068 & 0 & -1597.285 & 12 & 9592.022 & 192.672 & 0 & -4783.719 \\
\hline
\end{tabular}

${ }^{a}$ Density $(D)$ was modeled as varying only by session.

${ }^{b}$ All models employed half-normal detection function.

${ }^{c} \mathrm{~T}=$ trend $\mathrm{t}=$ time-varying, and session $=$ primary sampling periods .

Table 4. Estimates (Est.) of density ( $\hat{D}$; animals $\left.\cdot \mathrm{km}^{-2}\right), \sigma(\mathrm{km})$, and $\mathrm{g} 0$, with standard error (SE), of kit foxes (Vulpes macrotis) and coyotes (Canis latrans) in western Utah, USA, over winter (W) and summer (S) sessions from 2013 to 2014, based on multisession spatial capture-recapture models formulated as implemented with the R package "secr".

\begin{tabular}{|c|c|c|c|c|c|c|}
\hline \multirow[b]{2}{*}{ Session } & \multicolumn{2}{|l|}{$\hat{\hat{D}}$} & \multicolumn{2}{|l|}{$\sigma$} & \multicolumn{2}{|l|}{ g0 } \\
\hline & Est. & SE & Est. & SE & Est. & SE \\
\hline \multicolumn{7}{|l|}{ Kit fox ${ }^{a, c}$} \\
\hline W 2013 & 0.018 & 0.003 & 1.28 & 0.137 & 0.0013 & $<0.001$ \\
\hline S 2013 & 0.019 & 0.003 & 1.56 & 0.154 & 0.0008 & $<0.001$ \\
\hline W 2014 & 0.022 & 0.003 & 3.62 & 0.334 & 0.0002 & $<0.001$ \\
\hline S 2014 & 0.020 & 0.003 & 0.91 & 0.164 & 0.0024 & 0.002 \\
\hline \multicolumn{7}{|c|}{ Coyotes $^{b, c}$} \\
\hline W 2013 & 0.072 & 0.007 & 2.93 & 0.223 & 0.0001 & $<0.001$ \\
\hline S 2013 & 0.068 & 0.006 & 2.01 & 0.085 & 0.0005 & $<0.001$ \\
\hline W 2014 & 0.065 & 0.006 & 1.93 & 0.090 & 0.0006 & $<0.001$ \\
\hline S 2014 & 0.079 & 0.007 & 1.75 & 0.073 & 0.0008 & $<0.001$ \\
\hline
\end{tabular}

sponse to the removal of apex predators and anthropogenic disturbances (Gompper 2002). Although coyotes were rare at Dugway in the 1950s (Arjo et al. 2007), indices of coyote abundance (e.g., number taken per hour by predator control programs, scat deposition surveys) suggested that coyote abundance increased in the latter half of the 20th century (Arjo et al. 2007; Kozlowski et al. 2008). Despite an interest in coyote - kit fox interactions at Dugway (and elsewhere), coyote density estimates have not been reported for the site. Our coyote density estimates were the first generated for the area and suggested that the density estimates of coyotes were three to four times greater than those for kit foxes, supporting previous conclusions from relative abundance indices that coyotes have usurped kit foxes as the numerically dominant carnivore at Dugway (Arjo et al. 2007). Across their range, Knowlton et al. (1999) reported coyote densities ranging from 0.2 to 2.3 coyotes $\cdot \mathrm{km}^{-2}$, but lower densities $\left(0.14\right.$ coyotes $\left.\cdot \mathrm{km}^{-2}\right)$ have been reported where coyotes compete with kit foxes (Ralls and White 1995). Our density estimates are lower still $\left(<0.1\right.$ coyotes $\left.\cdot \mathrm{km}^{-2}\right)$ and may reflect relatively limited resources at the site when compared with other areas within their range.

\section{Species interactions and habitat associations}

It has been hypothesized that increased coyote abundance at Dugway was facilitated by increased water availability (Arjo et al. 2007; Kozlowski et al. 2012). Indeed, coyotes have higher water demands than kit foxes (Golightly and Ohmart 1984), and at our study site, coyotes were documented at water sources 231 times more than kit foxes (Hall et al. 2013). Our models incorporating distance to nearest water failed to converge, and we were unable to evaluate the influence of water on spatial variation in canid densities. Nonetheless, recent research found no relationship between coyote occupancy and proximity to water (Lonsinger et al. 2017), no response by coyotes to the removal of water sites (Kluever and Gese 2016), and no difference in detection of coyotes in areas with and without free water (Hall et al. 2013). Collectively, these studies provide multiple lines of evidence that water is not driving the spatial arrangement of coyotes at Dugway.

Kit fox population declines have been attributed to the influence of intraguild predation by coyotes, as well as habitat change and associated changes in prey communities (Arjo et al. 2007; Kozlowski et al. 2008, 2012; Byerly et al. 2018). Previous research suggested that coyotes selected shrubland habitats to maximize cover and prey, while kit foxes selected habitats that reduced predation risk (Nelson et al. 2007; Kozlowski et al. 2012). Our models incorporating spatial covariates received little to no support. Both canids are territorial and therefore density may be relatively similar across the study site. Alternatively, the resolution of our covariates, scale of study, or sample sizes may have been inadequate to model spatial variation in densities. Nevertheless, density can be estimated reliably with a homogenous density model, even when true density is heterogeneous (Efford and Fewster 2013).

The occupancy of kit foxes is suppressed by coyote activity at Dugway (Lonsinger et al. 2017). Equilibrium occupancy analyses suggested that kit fox occupancy may have stabilized in the presence of coyotes (Lonsinger et al. 2017). Our kit fox density estimates are comparable with estimates from 1997, suggesting that while kit fox populations have declined significantly since the mid-1950s, they may have stabilized over recent years. Kit foxes are territorial and generally monogamous (McGrew 1979); thus, stabilizing occupancy would be expected to occur in concert with stabilizing densities. Intraguild predation theory predicts that under conditions supporting stable coexistence, both the intraguild predator (e.g., coyotes) and intraguild prey (e.g., kit foxes) would occur at densities lower than either would occur individually (Holt and Polis 1997; Verdy and Amarasekare 2010). Our results align with these predictions. Despite seemingly dramatic increases in coyotes at Dugway, density estimates for coyotes are among the lowest reported, as are estimates for kit foxes.

At Dugway, recent home range size estimates for kit foxes (19.45-20.5 km²; Dempsey et al. 2014; Kluever and Gese 2017) were significantly larger than estimates reported across their range (2.5-11.6 km²; List and Cypher 2004). Recent estimates of coyote home ranges at Dugway (mean $=35.2 \mathrm{~km}^{2}$, standard error $(\mathrm{SE})=$ 2.3; Kluever and Gese 2016) also greatly exceeded estimates from other sites (5.5-6.9 km²; Gese et al. 1988; Nelson et al. 2007). These exceptionally large home ranges align with (i) our low density estimates for both species, (ii) reduced densities predicted by intraguild predation theory under patterns of stable coexistence (Holt and Polis 1997), and (iii) observed patterns in similar systems involving coexistence of sympatric canids (Kamler et al. 2013). For 
example, the density of Cape foxes (Vulpes chama (A. Smith, 1833)) was lower and the mean home range size was significantly larger $\left(27.7 \mathrm{~km}^{2}\right)$ in areas with dominant black-backed jackals (Canis mesomelas Schreber, 1775), when compared with densities and home range sizes $\left(9.2 \mathrm{~km}^{2}\right)$ in areas without jackals (Kamler et al. 2013). Kamler et al. (2013) suggested that the enlarged home range size may have allowed Cape foxes to employ spatiotemporal avoidance of jackals, while still using similar habitats and prey resources. Like Cape foxes, kit foxes at Dugway appear to employ broad-scale habitat partitioning and fine-scale resource matching (Lonsinger et al. 2017), while still accessing similar prey resources (Kozlowski et al. 2008; Byerly et al. 2018).

We failed to detect reproductive pulses (i.e., increases in abundance in the summer), and this likely reflects the precision of our estimates. Recaptures were less likely along single-occasion transects, and sampling these transects more than once may improve precision in future efforts. Alternatively, capture probability of juveniles may be lower along linear features. If nightly foraging events by juveniles are shorter in distance than those by adults, juveniles may have lower probability of encountering transects. If foraging events are shorter in duration or less frequent, juveniles may be less likely to deposit scats along a transect, even if one is encountered. One limitation of scat sampling was the inability to determine the age of individuals, and we therefore were unable to assess the potential for such differences.

\section{Management implications}

Challenges for many wildlife agencies are meeting their primary missions, affording adequate protection to natural resources and conserving sensitive species. Reliable and accurate estimates of population densities are paramount to making informed management decisions regarding sensitive species, and management agencies can benefit significantly from implementing the most effective and innovative approaches for monitoring populations. Our results demonstrated that NGS provided a viable and efficient strategy for concurrent monitoring of sympatric canids. Our conclusions, along with those of Lonsinger et al. (2017), suggest that while kit fox populations at Dugway have declined, populations have stabilized over recent years and kit foxes may be able to coexist with coyotes. Our study provided the first estimate of coyote density in this system and revealed that despite being widespread, coyote densities are quite low. Collectively, these findings clarify for managers the potential impact of coyotes on kit foxes and provide a framework for future population assessments. Our findings lacked the precision to detect seasonal changes in abundance. A common benefit to NGS is that an individual may be captured $>1$ time in a given capture event. The large estimated home range size of both species at Dugway, combined with the dispersed sampling strategy (i.e., not sampling at concentration points and (or) baiting), though, may have reduced recaptures and influenced the precision of our estimates. If managers desire improved precision of future estimates, it will likely be necessary to sample all sites more than once.

\section{Acknowledgements}

We thank B. Kluever, E. Burke, J. Decotis, T. Edwards, M. Melham, C. Perkins, M. Richmond, and M. Smith for assistance with fieldwork and J. Adams and Waits Lab technicians for assistance with laboratory procedures. We thank the U.S. Army Dugway Proving Ground Natural Resource Management Program, namely K. Marvel, M. Peters, R. Delph, and J. Delph, for logistical support. The Utah Division of Wildlife Resources provided housing. This work was funded in part by the U.S. Army Research Laboratory and the U.S. Army Research Office (Grant RC-201205), the U.S. Department of Defense Environmental Security Technology Certification (Grant 12 EB-RC5-006) and Legacy Resource Management (Grant W9132T12-2-0050) programs, the U.S. Department of Agriculture, Wildlife Services, National Wildlife Research Center, the National Geo- graphic Society's Conservation Trust (Grant C248-13), and T\&E, Inc. Two anonymous reviewers provided useful comments on an earlier version of the manuscript.

\section{References}

Arjo, W.M., Bennett, T.J., and Kozlowski, A.J. 2003. Characteristics of current and historical kit fox (Vulpes macrotis) dens in the Great Basin Desert. Can. J. Zool. 81(1): 96-102. doi:10.1139/z02-232.

Arjo, W.M., Gese, E.M., Bennett, T.J., and Kozlowski, A.J. 2007. Changes in kit fox-coyote-prey relationships in the Great Basin Desert, Utah. West. N. Am. Nat. 67(3): 389-401. doi:10.3398/1527-0904(2007)67[389:CIKFRI]2.0.CO;2.

Berry, O., Sarre, S.D., Farrington, L., and Aitken, N. 2007. Faecal DNA detection of invasive species: the case of feral foxes in Tasmania. Wildl. Res. 34(1): 1-7. doi:10.1071/WR06082.

Blanc, L., Marboutin, E., Gatti, S., and Gimenez, O. 2013. Abundance of rare and elusive species: empirical investigation of closed versus spatially explicit capture-recapture models with lynx as a case study. J. Wildl. Manage. 77(2): 372-378. doi:10.1002/jwmg.453.

Borchers, D.L., and Efford, M.G. 2008. Spatially explicit maximum likelihood methods for capture-recapture studies. Biometrics, 64(2): 377-385. doi:10. 1111/j.1541-0420.2007.00927.x. PMID:17970815.

Brøseth, H., Flagstad, Ø., Wärdig, C., Johansson, M., and Ellegren, H. 2010. Largescale noninvasive genetic monitoring of wolverines using scats reveals density dependent adult survival. Biol. Conserv. 143(1): 113-120. doi:10.1016/j. biocon.2009.09.012.

Burnham, K.P., and Anderson, D.R. 2002. Model selection and multimodel inference: a practical information-theoretic approach. 2nd ed. Springer USA, New York.

Byerly, P.A., Lonsinger, R.C., Gese, E.M., Kozlowski, A.J., and Waits, L.P. 2018. Resource partitioning between kit foxes (Vulpes macrotis) and coyotes (Canis latrans): a comparison of historical and contemporary dietary overlap. Can. J. Zool. 96(5): 497-504. doi:10.1139/cjz-2017-0246.

Creel, S., Spong, G., Sands, J.L., Rotella, J., Zeigle, J., Joe, L., Murphy, K.M., and Smith, D. 2003. Population size estimation in Yellowstone wolves with errorprone noninvasive microsatellite genotypes. Mol. Ecol. 12(7): 2003-2009. doi: 10.1046/j.1365-294X.2003.01868.x. PMID:12803649.

Cullingham, C.I., Smeeton, C., and White, B.N. 2006. Isolation and characterization of swift fox tetranucleotide microsatellite loci. Mol. Ecol. Notes, 7(1): 160-162. doi:10.1111/j.1471-8286.2006.01565.x.

Cypher, B.L., and Spencer, K.A. 1998. Competitive interactions between coyotes and San Joaquin kit foxes. J. Mammal. 79(1): 204-214. doi:10.2307/1382855.

De Barba, M., Adams, J.R., Goldberg, C.S., Stansbury, C.R., Arias, D., Cisneros, R., and Waits, L.P. 2014. Molecular species identification for multiple carnivores. Conserv. Genet. Resour. 6(4): 821-824. doi:10.1007/s12686-014-0257-x.

Dempsey, S.J., Gese, E.M., and Kluever, B.M. 2014. Finding a fox: an evaluation of survey methods to estimate abundance of a small desert carnivore. PLoS ONE, 9(8): e105873. doi:10.1371/journal.pone.0105873. PMID:25148102.

Dempsey, S.J., Gese, E.M., Kluever, B.M., Lonsinger, R.C., and Waits, L.P. 2015. Evaluation of scat deposition transects versus radio telemetry for developing a species distribution model for a rare desert carnivore, the kit fox. PLoS ONE, 10(10): e0138995. doi:10.1371/journal.pone.0138995. PMID:26465332.

Efford, M.G. 2015. secr: spatially explicit capture-recapture models. R Package version 2.9.4. Available from http://CRAN.R-project.org/package=secr.

Efford, M.G., and Fewster, R.R.M. 2013. Estimating population size by spatially explicit capture-recapture. Oikos, 122(6): 918-928. doi:10.1111/j.1600-0706.2012. 20440.x.

Efford, M.G., Borchers, D.L., and Byrom, A.E. 2009. Density estimation by spatially explicit capture-recapture: likelihood-based methods. In Modeling demographic processes in marked populations. Edited by D.L. Thomson, E.G. Cooch, and M.J. Conroy. Springer, USA. pp. 255-269.

Egoscue, H.J. 1956. Preliminary studies of the kit fox in Utah. J. Mammal. 37(3): 351-357. doi:10.2307/1376734.

Egoscue, H.J. 1962. Ecology and life history of the kit fox in Tooele County, Utah. Ecology, 43(3): 481-497. doi:10.2307/1933376.

Egoscue, H.J. 1975. Population dynamics of the kit fox in western Utah. Bull. South. Calif. Acad. Sci. 74: 122-127.

Eichmann, C., Berger, B., and Parson, W. 2004. A proposed nomenclature for 15 canine-specific polymorphic STR loci for forensic purposes. Int. J. Legal Med. 118(5): 249-266. doi:10.1007/s00414-004-0452-5. PMID:15168130.

Francisco, L., Langston, A., Mellersh, C., Neal, C., and Ostrander, E. 1996. A class of highly polymorphic tetranucleotide repeats for canine genetic mapping. Mamm. Genome, 7: 359-362. doi:10.1007/s003359900104. PMID:8661717.

Fredholm, M., and Wintero, A. 1995. Variation of short tandem repeats within and between species belonging to the Canidae family. Mamm. Genome, 6(1): 11-18. doi:10.1007/BF00350887. PMID:7719020.

Gese, E.M. 2001. Monitoring of terrestrial carnivore populations. In Carnivore conservation. Edited by J.L. Gittleman, S.M. Funk, D. Macdonald, and R.K. Wayne. University Press, Cambridge. pp. 372-396.

Gese, E.M., Rongstad, O.J., and Mytton, W.R. 1988. Home range and habitat use of coyotes in southeastern Colorado. J. Wildl. Manage. 52(4): 640-646. doi:10. $2307 / 3800923$ 
Golightly, R.T., and Ohmart, R.D. 1984. Water economy of two desert canids: coyote and kit fox. J. Mammal. 65(1): 51-58. doi:10.2307/1381199.

Gompper, M.E. 2002. Top carnivores in the suburbs? Ecological and conservation issues raised by colonization of north eastern North America by coyotes. Bioscience, 52(2): 185-190. doi:10.1641/0006-3568(2002)052[0185:TCITSE]2.0. $\mathrm{CO} ; 2$.

Granjon, A.-C., Rowney, C., Vigilant, L., and Langergraber, K.E. 2017. Evaluating genetic capture-recapture using a chimpanzee population of known size. J. Wildl. Manage. 81(2): 279-288. doi:10.1002/jwmg.21190.

Guyon, R., Lorentzen, T.D., Hitte, C., Kim, L., Cadieu, E., Parker, H.G., Quignon, P., Lowe, J.K., Renier, C., Gelfenbeyn, B., Vignaux, F., DeFrance, H.B., Gloux, S., Mahairas, G.G., André, C., Galibert, F., and Ostrander, E.A. 2003. A 1-Mb resolution radiation hybrid map of the canine genome. Proc. Natl. Acad. Sci. U.S.A. 100(9): 5296-5301. doi:10.1073/pnas.0831002100. PMID:12700351.

Hall, L.K., Larsen, R.T., Knight, R.N., Bunnell, K.D., and McMillan, B.R. 2013. Water developments and canids in two North American deserts: a test of the indirect effect of water hypothesis. PLoS ONE, 8(7): e67800. doi:10.1371/journal. pone.0067800. PMID:23844097.

Holmes, N.G., Dickens, H.F., Parker, H.L., Binns, M.M., Mellersh, C.S., and Sampson, J. 1995. Eighteen canine microsatellites. Anim. Genet. 26(2): 132133. PMID:7733507.

Holt, R.D., and Polis, G.A. 1997. A theoretical framework for intraguild predation. Am. Nat. 149(4): 745-764. doi:10.1086/286018.

Kamler, J.F., Stenkewitz, U., and Macdonald, D.W. 2013. Lethal and sublethal effects of black-backed jackals on cape foxes and bat-eared foxes. J. Mammal. 94(2): 295-306. doi:10.1644/12-MAMM-A-122.1.

Kelly, M.J., Betsch, J., Wultsch, C., Mesa, B., and Mills, L.S. 2012. Noninvasive sampling of carnivores. In Carnivore ecology and conservation: a handbook of techniques. Edited by L. Boitani and R.A. Powell. Oxford University Press, Oxford. pp. 47-69.

Kluever, B.M., and Gese, E.M. 2016. Spatial response of coyotes to removal of water availability at anthropogenic water sites. J. Arid Environ. 130: 68-75. doi:10.1016/j.jaridenv.2016.03.009.

Kluever, B.M., and Gese, E.M. 2017. Evaluating the influence of water developments on the demography and spatial ecology of a rare, desert-adapted carnivore: the kit fox (Vulpes macrotis). J. Mammal. 98(3): 815-826. doi:10.1093/ jmammal/gyx038.

Kluever, B.M., Gese, E.M., Dempsey, S.J., and Knight, R.N. 2013. A comparison of methods for monitoring kit foxes at den sites. Wildl. Soc. Bull. 37(2): 439443. doi:10.1002/wsb.261.

Kluever, B.M., Gese, E.M., and Dempsey, S.J. 2015. The influence of road characteristics and species on detection probabilities of carnivore faeces. Wildl. Res. 42(1): 75-82. doi:10.1071/WR14244.

Kluever, B.M., Gese, E.M., and Dempsey, S.J. 2017. Influence of free water availability on a desert carnivore and herbivore. Curr. Zool. 63(2): 121-129. PMID: 29491969.

Knowlton, F.F., Gese, E.M., and Jaeger, M.M. 1999. Coyote depredation control: an interface between biology and management. J. Range Manage. 52(5): 398412. doi:10.2307/4003765.

Kohn, M.H., York, E.C., Kamradt, D.A., Haught, G., Sauvajot, R.M., and Wayne, R.K. 1999. Estimating population size by genotyping faeces. Proc. R. Soc. Ser. B Biol. Sci. 266(1420): 657-663. doi:10.1098/rspb.1999.0686

Kozlowski, A.J., Gese, E.M., and Arjo, W.M. 2008. Niche overlap and resource partitioning between sympatric kit foxes and coyotes in the Great Basin Desert of western Utah. Am. Midl. Nat. 160(1): 191-208. doi:10.1674/00030031(2008)160[191:NOARPB]2.0.CO;2.

Kozlowski, A.J., Gese, E.M., and Arjo, W.M. 2012. Effects of intraguild predation: evaluating resource competition between two canid species with apparent niche separation. Int. J. Ecol. 2012: 629246. doi:10.1155/2012/629246.

List, R., and Cypher, B.L. 2004. Kit fox. In Canids: foxes, wolves, jackals, and dogs. Status Survey and Conservation Action Plan. Edited by D.W. MacDonald. IUCN/SSC Canid Specialist Group, Gland, Switzerland and Cambridge, U.K. pp. 105-109.

Lonsinger, R.C., and Waits, L.P. 2015. ConGenR: rapid determination of consensus genotypes and estimates of genotyping errors from replicated genetic samples. Conserv. Genet. Resour. 7(4): 841-843. doi:10.1007/s12686-015-0506-7.

Lonsinger, R.C., Gese, E.M., Dempsey, S.J., Kluever, B.M., Johnson, T.R., and Waits, L.P. 2015a. Balancing sample accumulation and DNA degradation rates to optimize noninvasive genetic sampling of sympatric carnivores. Mol. Ecol. Resour. 15(4): 831-842. doi:10.1111/1755-0998.12356. PMID:25454561.

Lonsinger, R.C., Gese, E.M., and Waits, L.P. 2015b. Evaluating the reliability of field identification and morphometric classifications for carnivore scats confirmed with genetic analysis. Wildl. Soc. Bull. 39(3): 593-602. doi:10.1002/wsb. 549.

Lonsinger, R.C., Gese, E.M., Knight, R.N., Johnson, T.R., and Waits, L.P. 2016. Quantifying and correcting for scat removal in noninvasive carnivore scat surveys. Wildl. Biol. 22(2): 45-54. doi:10.2981/wlb.00179.

Lonsinger, R.C., Gese, E.M., Bailey, L.L., and Waits, L.P. 2017. The roles of habitat and intraguild predation by coyotes on the spatial dynamics of kit foxes. Ecosphere, 8(3): e01749. doi:10.1002/ecs2.1749.

Lukacs, P.M., and Burnham, K.P. 2005. Review of capture-recapture methods applicable to noninvasive genetic sampling. Mol. Ecol. 14: 3909-3919. doi:10. 1111/j.1365-294X.2005.02717.x. PMID:16262847.
Manning, J.A., and Goldberg, C.S. 2010. Estimating population size using capturerecapture encounter histories created from point-coordinate locations of animals. Methods Ecol. Evol. 1(4): 389-397. doi:10.1111/j.2041-210X.2010.00041.x.

McGrew, J.C. 1979. Vulpes macrotis. Mamm. Species Accounts, 123: 1-6.

McLaughlin, M.A. 1979. Density, distribution, and status of the kit fox in TransPecos, Texas. Texas A\&M University.

Miller, C.R., Joyce, P., and Waits, L.P. 2002. Assessing allelic dropout and genotyping reliability using maximum likelihood. Genetics, 160: 357-366. PMID: 11805071.

Miller, C.R., Joyce, P., and Waits, L.P. 2005. A new method for estimating the size of small populations from genetic mark-recapture data. Mol. Ecol. 14: 19912005. doi:10.1111/j.1365-294X.2005.02577.x. PMID:15910321.

Morin, D.J., Kelly, M.J., and Waits, L.P. 2016. Monitoring coyote population dynamics with fecal DNA and spatial capture-recapture. J. Wildl. Manage. 80(5): 824-836. doi:10.1002/jwmg.21080.

Mumma, M.A., Zieminski, C., Fuller, T.K., Mahoney, S.P., and Waits, L.P. 2015. Evaluating noninvasive genetic sampling techniques to estimate large carnivore abundance. Mol. Ecol. Resour. 15(5): 1133-1144. doi:10.1111/1755-0998. 12390. PMID:25693632.

Nelson, J.L., Cypher, B.L., Bjurlin, C.D., and Creel, S. 2007. Effects of habitat on competition between kit foxes and coyotes. J. Wildl. Manage. 71(5): 14671475. doi:10.2193/2006-234.

Ostrander, E.A., Sprague, G.F., and Rine, J. 1993. Identification and characterization of dinucleotide repeat $(\mathrm{CA})_{n}$ markers for genetic mapping in dog. Genomics, 16: 207-213. doi:10.1006/geno.1993.1160. PMID:8486359.

Ostrander, E.A., Mapa, F.A., Yee, M., and Rine, J. 1995. One hundred and one new simple sequence repeat-based markers for the canine genome. Mamm. Genome, 6: 192-195. doi:10.1007/BF00293011. PMID:7749226.

Paetkau, D. 2003. An empirical exploration of data quality in DNA-based population inventories. Mol. Ecol. 12(6): 1375-1387. doi:10.1046/j.1365-294X.2003. 01820.x. PMID:12755868.

Peakall, R., and Smouse, P.E. 2006. genalex 6: genetic analysis in Excel. Population genetic software for teaching and research. Mol. Ecol. Notes, 6(1): 288295. doi:10.1111/j.1471-8286.2005.01155.x.

Pollock, K.H., Nichols, J.D., Simons, T.R., Farnsworth, G.L., Bailey, L.L., and Sauer, J.R. 2002. Large scale wildlife monitoring studies: statistical methods for design and analysis. Environmetrics, 13(2): 105-119. doi:10.1002/env.514.

$\mathrm{R}$ Core Team. 2015. R: a language and environment for statistical computing. R Foundation for Statistical Computing, Vienna, Austria. Available from http:// www.R-project.org.

Ralls, K., and White, P.J. 1995. Predation on San Joaquin kit foxes by larger canids. J. Mammal. 76(3): 723-729. doi:10.2307/1382743.

Russell, R.E., Royle, J.A., Desimone, R., Schwartz, M.K., Edwards, V.L., Pilgrim, K.P., and McKelvey, K.S. 2012. Estimating abundance of mountain lions from unstructured spatial sampling. J. Wildl. Manage. 76(8): 1551-1561. doi:10.1002/jwmg.412.

Schwartz, M.K., Luikart, G., and Waples, R.S. 2007. Genetic monitoring as a promising tool for conservation and management. Trends Ecol. Evol. 22(1): 25-33. doi:10.1016/j.tree.2006.08.009. PMID:16962204.

Seddon, J.M. 2005. Canid-specific primers for molecular sexing using tissue or non-invasive samples. Conserv. Genet. 6(1): 147-149. doi:10.1007/s10592-0047734-9.

Seutin, G., White, B.N., and Boag, P.T. 1991. Preservation of avian blood and tissue samples for DNA analyses. Can. J. Zool. 69(1): 82-90. doi:10.1139/z91-013.

Smith, D.A., Ralls, K., Hurt, A., Adams, B., Parker, M., and Maldonado, J.E. 2006. Assessing reliability of microsatellite genotypes from kit fox faecal samples using genetic and GIS analyses. Mol. Ecol. 15: 387-406. doi:10.1111/j.1365-294X. 2005.02841.x. PMID:16448408.

Solberg, K.H., Bellemain, E., Drageset, O.-M., Taberlet, P., and Swenson, J.E. 2006. An evaluation of field and non-invasive genetic methods to estimate brown bear (Ursus arctos) population size. Biol. Conserv. 128(2): 158-168. doi:10.1016/ j.biocon.2005.09.025.

Stansbury, C.R., Ausband, D.E., Zager, P., Mack, C.M., Miller, C.R., Pennell, M.W., and Waits, L.P. 2014. A long-term population monitoring approach for a wide-ranging carnivore: noninvasive genetic sampling of gray wolf rendezvous sites in Idaho, USA. J. Wildl. Manage. 78(6): 1040-1049. doi:10.1002/jwmg. 736.

Stenglein, J.L., De Barba, M., Ausband, D.E., and Waits, L.P. 2010a. Impacts of sampling location within a faeces on DNA quality in two carnivore species. Mol. Ecol. Resour. 10(1): 109-114. doi:10.1111/j.1755-0998.2009.02670.x. PMID: 21564995.

Stenglein, J.L., Waits, L.P., Ausband, D.E., Zager, P., and Mack, C.M. 2010b. Efficient, noninvasive genetic sampling for monitoring reintroduced wolves. J. Wildl. Manage. 74(5): 1050-1058. doi:10.2193/2009-305.

Taberlet, P., Griffin, S., Goossens, B., Questiau, S., Manceau, V., Escaravage, N., Waits, L.P., and Bouvet, J. 1996. Reliable genotyping of samples with very low DNA quantities using PCR. Nucleic Acids Res. 24(16): 3189-3194. doi:10.1093/ nar/24.16.3189. PMID:8774899.

Thompson, C.M., Royle, J.A., and Garner, J.D. 2012. A framework for inference about carnivore density from unstructured spatial sampling of scat using detector dogs. J. Wildl. Manage. 76(4): 863-871. doi:10.1002/jwmg.317. 
U.S. Fish and Wildlife Service (USFWS). 1998. Recovery plan for upland species of the San Joaquin Valley, California. U.S. Fish and Wildlife Service, Portland, Oregon.

Verdy, A., and Amarasekare, P. 2010. Alternative stable states in communities with intraguild predation. J. Theor. Biol. 262(1): 116-128. doi:10.1016/j.jtbi.2009. 09.011. PMID:19765596.

Waits, L.P., and Paetkau, D. 2005. Noninvasive genetic sampling tools for wildlife biologists: a review of applications and recommendations for accurate data collection. J. Wildl. Manage. 69(4): 1419-1433. doi:10.2193/0022-541X(2005)69[1419: NGSTFW]2.0.CO;2.

Waits, L.P., Luikart, G., and Taberlet, P. 2001. Estimating the probability of identity among genotypes in natural populations: cautions and guidelines. Mol. Ecol. 10(1): 249-256. doi:10.1046/j.1365-294X.2001.01185.x. PMID:11251803.

White, P.J., and Garrott, R.A. 1999. Population dynamics of kit foxes. Can. J. Zool. 77(3): 486-493. doi:10.1139/z99-007.

Williams, B.K., Nichols, J.D., and Conroy, M.J. 2002. Analysis and management of animal populations. Academic Press, San Diego, Calif.

Williams, B.W., Etter, D.R., Linden, D.W., Millenbah, K.F., Winterstein, S.R., and Scribner, K.T. 2009. Noninvasive hair sampling and genetic tagging of codistributed fishers and American martens. J. Wildl. Manage. 73(1): 26-34. doi:10.2193/2007-429.

Zoellick, B.W., and Smith, N.S. 1992. Size and spatial organization of home ranges of kit foxes in Arizona. J. Mammal. 73(1): 83-88. doi:10.2307/1381868.

\section{Appendix A}

Table A1. Ranking of multisession spatially explicit capture-recapture models fit with the $\mathrm{R}$ package "secr" for kit fox (Vulpes macrotis) and coyote (Canis latrans) densities (D) in western Utah, USA, 2013-2014.

\begin{tabular}{|c|c|c|c|c|c|}
\hline Model $^{a, b}$ & K & $\mathrm{AIC}_{\mathrm{c}}$ & $\Delta \mathrm{AIC}_{\mathrm{c}}$ & $w_{\mathrm{i}}$ & LL \\
\hline \multicolumn{6}{|l|}{ Kit fox ${ }^{c}$} \\
\hline$D$ (session) & 20 & 3146.57 & 0 & 1 & -1550.348 \\
\hline$D($ session $+\mathrm{SW})$ & 21 & 3283.12 & 136.56 & 0 & -1617.308 \\
\hline$D($ session $+S W+\operatorname{sex})$ & 22 & 3283.77 & 137.20 & 0 & -1616.296 \\
\hline$D($ session + soil $)$ & 24 & 3285.05 & 138.48 & 0 & -1614.206 \\
\hline$D($ session $\times S W)$ & 24 & 3291.10 & 144.53 & 0 & -1617.233 \\
\hline$D($ session $\times S W \times \operatorname{sex})$ & 32 & 3310.40 & 163.83 & 0 & -1615.138 \\
\hline$D($ session $\times$ soil $)$ & 36 & 3322.66 & 176.10 & 0 & -1614.844 \\
\hline$D$ (session + habitat $)$ & 24 & 3340.95 & 194.38 & 0 & -1642.157 \\
\hline$D($ session $+x+y)$ & 22 & 3358.19 & 211.62 & 0 & -1653.508 \\
\hline$D(\operatorname{session} \times x+y)$ & 25 & 3362.83 & 216.26 & 0 & -1651.704 \\
\hline$D$ (Session) & 18 & 3364.84 & 218.27 & 0 & -1662.060 \\
\hline$D($ session $+\operatorname{sex})$ & 21 & 3368.19 & 221.62 & 0 & -1659.841 \\
\hline$D($ session $\times$ habitat $)$ & 36 & 3369.94 & 223.37 & 0 & -1638.482 \\
\hline$D(\operatorname{session} \times \operatorname{sex})$ & 24 & 3373.22 & 226.65 & 0 & -1658.293 \\
\hline \multicolumn{6}{|l|}{ Coyote $^{d}$} \\
\hline$D$ (session) & 44 & 9399.35 & 0 & 1 & -4651.731 \\
\hline$D(\operatorname{session}+x+y)$ & 46 & 10128.05 & 728.70 & 0 & -5013.702 \\
\hline$D$ (session + habitat $)$ & 48 & 10128.65 & 729.30 & 0 & -5011.603 \\
\hline$D($ session $\times \mathrm{SW})$ & 48 & 10130.35 & 731.00 & 0 & -5012.450 \\
\hline$D$ (Session) & 42 & 10131.31 & 731.96 & 0 & -5020.073 \\
\hline$D($ session $\times x+y)$ & 49 & 10134.78 & 735.43 & 0 & -5013.461 \\
\hline$D($ session $+\mathrm{SW})$ & 45 & 10136.34 & 736.99 & 0 & -5019.038 \\
\hline$D($ session + sex $)$ & 45 & 10136.71 & 737.36 & 0 & -5019.222 \\
\hline$D($ session $\times$ habitat $)$ & 60 & 10136.71 & 737.36 & 0 & -5000.824 \\
\hline$D($ session $+\mathrm{SW}+\mathrm{sex})$ & 46 & 10139.02 & 739.67 & 0 & -5019.184 \\
\hline$D($ session + soil $)$ & 48 & 10139.04 & 739.69 & 0 & -5016.797 \\
\hline$D(\operatorname{session} \times \operatorname{sex})$ & 48 & 10142.46 & 743.11 & 0 & -5018.508 \\
\hline$D(\operatorname{session} \times \mathrm{SW} \times \operatorname{sex})$ & 56 & 10146.45 & 747.10 & 0 & -5010.712 \\
\hline$D($ session $\times$ soil $)$ & 60 & 10157.53 & 758.18 & 0 & -5011.234 \\
\hline
\end{tabular}

Note: session, varying among sessions; Session, trend among sessions; $x+y$, linear trend surface; habitat, categorical habitat classifications; SW, proportion of site characterized as shrubland or woodland; soil, categorical soil classifications; sex, sex groupings. Model support was evaluated based on Akaike's information criterion with small sample size correction $\left(\mathrm{AIC}_{\mathrm{c}}\right)$. Each model is ranked based on $\Delta \mathrm{AIC}_{\mathrm{c}}$, where $K$ is the number of parameters, $w_{\mathrm{i}}$ represents Akaike weight, and LL is log-likelihood.

${ }^{a}$ Models for $g 0$ and $\sigma$ (which jointly describe capture probability) are described in footnotes $c$ and $d$.

${ }^{b}$ All models employed half-normal detection function.

${ }^{c}$ Capture probability modeled as $g 0 \sim \mathrm{T} \times \operatorname{session}$ and $\sigma \sim \mathrm{T} \times \operatorname{session}(\mathrm{T}=$ trend).

${ }^{d}$ Capture probability modeled as $g 0 \sim \mathrm{t} \times \operatorname{session}$ and $\sigma \sim \mathrm{t} \times \operatorname{session}(\mathrm{t}=$ time-varying). 